УДК 316 (485)

Злобіна Олена Геннадіївна

доктор соиіологічних наук, професор, Інститут соціології НАН України,

Київ, Україна, ezlobina@ukr.net

\title{
ДИНАМІКА УЯВЛЕНЬ НАСЕЛЕННЯ УКРАЇНИ ПРО УКРАЇНО-РОСІЙСЬКІ ВІДНОСИНИ В УМОВАХ НАПРУЖЕНОСТІ МІЖДЕРЖАВНИХ СТОСУНКІВ (2014-2017 pp.)
}

Метою дослідження $€$ виявлення характерних тенденцій у змінах уявлень населення України про стосунки між Україною та Росією на тлі сталої міждержавної напруженості. Аналізуються емпіричні дані соціологічного моніторингу «Українське суспільство», який здійснюється Інститутом соціології НАН України у вигляді щорічних всеукраїнських репрезентативних опитувань, починаючи 31992 р. До аналізу залучено також результати всеукраїнських репрезентативних соціологічних опитувань провідних українських соціологічних центрів. У результаті дослідження виявлено тенденції змін в уявленнях населення України про стан україно-російських стосунків. Згідно отриманих даних, констатується, що попри постійне відтворення напруженості внаслідок конфлікту на Сході країни, у масовій свідомості фіксується певне зниження негативних диспозицій стосовно російсько-українських відносин. Під впливом фактичного міждержавного дистанціювання, яке послідовно відбувається у економічній, політичній та культурній сферах, поступово зменшується прагнення до різкого розмежування з Росією, яка втрачає статус «особливого» сусіда. Натомість формується нове сприйняття Росії як країни, стосунки 3 якою мають грунтуватися на загальних засадах побудови міждержавних стосунків, так само, як і з іншими країнами. Підтверджено, що громадська думка населення України щодо того, яким має бути бажаний характер відносин 3 Росією, значною мірою диференційована внаслідок відмінностей політико-ідеологічних настанов різних соціальних груп і має чіткі регіональні відмінності: на Заході превалює тенденція до дистанціювання, на Півдні та Сході сильнішою $є$ схильність до відновлення добросусідських відносин, у центральному регіоні відповідні настанови представлені у рівних пропорціях.

Ключові слова: соціальна напруженість, міждержавні відносини, Україна, Росія, масова свідомість, регіональні відмінності. 


\section{ДИНАМІКА УЯВЛЕНЬ НАСЕЛЕННЯ УКРАЇНИ ПРО \\ УКРАЇНО-РОСІЙСЬКІ ВІДНОСИНИ В УМОВАХ НАПРУЖЕНОСТІ \\ МІЖДЕРЖАВНИХ СТОСУНКІВ (2014-2017 рр.)}

Zlobina Olena, Doctor of Sociological Sciences, Professor, Institute of Sociology of the National Academy of Sciences of Ukraine, Kyiv, Ukraine

Dynamics of the Ukraianian population perception of the relations between Ukraine and Russia in the conditions of permanent interstate tensions (2014-2017)

The main objective of the study is to identify the characteristic trends of the Ukrainian population perception changes of the relations between Ukraine and Russia against the backdrop of constant interstate tensions. The article analyzes the empirical data of the "Ukrainian Society" sociological monitoring, carried out by the Institute of Sociology of the National Academy of Sciences of Ukraine in the form of annual allUkrainian representative polls, taken place since 1992. The analysis also addressed to the all-Ukrainian representative polls results obtained by the leading Ukrainian sociological centers. As a result of the research, there were revealed the tendencies of changes of the Ukrainian population views about the Ukrainian-Russian relations state. According to the received data, it is established that despite a constant reproduction of tension as a result of the conflict taking place in the east of the country, the Ukrainian masses show a certain decrease of negative dispositions in relation to relations between Russia and Ukraine. Under the influence of an actual inter-state distancing, consistently occuring in the economic, political and cultural spheres, the desire for a sharp separation from Russia, losing the status of a "special" neighbor" is gradually decreasing. A new perception of Russia as a country is being formed. According to this perception the relations with Russia should be based on the common grounds for building interstate relations, as well as with other countries. It has been confirmed that the public opinion of the Ukrainian population concerning the desired character of the relations with Russia is largely been differentiated as a consequence of the differences within the various social groups political and ideological attitudes, thus having clear regional differences: in the West, domains the tendency to distance, in the South and East, the propensity to restore good-neighborly relations is stronger, in the Central region the corresponding dispositions are presented in equal proportions.

Key words: social tension, interstate relations, Ukraine, Russia, mass consciousness, regional differences.

Злобина Елена Геннадьевна, доктор сочиологических наук, профессор, Институт соииологии НАН Украины, Киев, Украина

Динамика представлений населения Украины об украинороссийских отношениях в условиях напряженности межгосударственных отношений (2014-2017 гг.) 


\section{ДИНАМІКА УЯВЛЕНЬ НАСЕЛЕННЯ УКРАЇНИ ПРО \\ УКРАЇНО-РОСІЙСЬКІ ВІДНОСИНИ В УМОВАХ НАПРУЖЕНОСТІ \\ МІЖДЕРЖАВНИХ СТОСУНКІВ (2014-2017 рр.)}

Целью исследования является выявление характерных тенденций в изменениях представлений населения Украины об отношениях между Украиной и Россией на фоне постоянной межгосударственной напряженности. Анализируются эмпирические данные социологического мониторинга «Украинское общество», который осуществляется Институтом социологии НАН Украины в виде ежегодных всеукраинских репрезентативных опросов, начиная с 1992 г. В анализе использованы также результаты всеукраинских репрезентативных опросов ведущих украинских социологических центров. В результате исследования выявлены тенденции изменений в представлениях населения Украины о состоянии украино-российских отношений. Согласно полученным данным констатируется, что, несмотря на постоянное воспроизводство напряженности в результате конфликта на востоке страны, в массовом сознании фиксируется некоторое снижение негативных диспозиций относительно российско-украинских отношений. Под влиянием фактического межгосударственного дистанцирования, которое последовательно происходит в экономической, политической и культурной сферах, постепенно уменьшается стремление к резкому отмежеванию от России, которая теряет статус «особого» соседа. Формируется новое восприятие России как страны, отношения с которой должны основываться на общих основаниях построения межгосударственных отношений, так же, как и с другими странами. Подтверждено, что общественное мнение населения Украины относительно того, каким должен быть желаемый характер отношений с Россией, в значительной степени дифференцировано в зависимости от различий политико-идеологических установок различных социальных групп и имеет четкие региональные различия: на Западе превалирует тенденция к дистанциированию, на Юге и Востоке сильнее выражена склонность к восстановлению добрососедских отношений, в центральном регионе соответствующие диспозиции представлены в равных пропорциях.

Ключевые слова: социальная напряженность, межгосударственные отношения, Украина, Россия, массовое сознание, региональные отличия.

Вступ. Дослідженню динаміки уявлень населення України та Росії про стосунки між країнами на тлі стрімкої зміни міждержавних відносин в останні роки стало предметом пильної уваги соціологів [1]. Актуальність теми великою мірою пов'язана із тим, що саме в таких взаєминах народжується і набирає силу соціальна напруженість. Цей стан підсилюється внаслідок дестабілізації соціально-економічних, соціально-політичних або культурних відносин. Навіть у стабільних, високорозвинених країнах час від часу виникають осередки напруги, пов'язані з дією як внутрішніх, так і зовнішніх чинників. 


\section{ДИНАМІКА УЯВЛЕНЬ НАСЕЛЕННЯ УКРАЇНИ ПРО \\ УКРАЇНО-РОСІЙСЬКІ ВІДНОСИНИ В УМОВАХ НАПРУЖЕНОСТІ \\ МІЖДЕРЖАВНИХ СТОСУНКІВ (2014-2017 рр.)}

Постановка завдання. Складність феномену соціальної напруженості потребує введення координат для розрізнення видів напруженості. Слід насамперед виділити «змістовний рівень» соціальної напруженості, який охоплює перелік актуальних проблем, що стосуються окремих соціальних груп різною мірою. Зміст актуальних проблем $€$ ключовим у виокремленні структурних особливостей соціальної напруженості.

Виклад основного матеріалу. Фактично у масовій свідомості формується певна узагальнена оцінка ситуації в суспільстві як більш або менш напруженої, яка складається з різних компонентів. На змістовному рівні у масовій свідомості фіксуються відрефлексовані «зовнішні» чинники напруженості, які операціоналізуються в дослідженнях через перелік економічних, соціальних чи політичних проблем, що викликають соціальну напруженість.

Для виокремлення ключових чинників формування змістовної картини соціальної напруженості українського суспільства на даний момент, звернемося до аналізу даних моніторингово опитування Інституту соціології НАНУ 2017 p. ${ }^{1}$

Для отримання узагальненої оцінки в опитуванні було поставлено запитання «Як би Ви охарактеризували рівень напруженості в суспільстві сьогодні?» Респонденти мали оцінити ситуацію за десятибальною шкалою (від 1 - «ситуація спокійна», рівень напруженості дуже низький, до 10 «ситуація критична, вибухонебезпечна», рівень напруженості вкрай високий).

Рівень напруженості у суспільстві більшість населення (61\%) оцінило як високий: «вкрай високий» $(23 \%)$ та «вище середнього» $(38 \%)$. За десятибальною шкалою середній бал напруженості становить на сьогодні 6,79 бала. Впливовість чинників, які сприяють зростанню напруженості, респондентам пропонувалося оцінити на основі вибору із запропонованого переліку того, що на їхню думку найбільшою мірою впливає на зростання напруженості в суспільстві останнім часом.

Головною причиною соціальної напруженості більшість опитаних $(67,9 \%)$ назвала бойові дії на Сході країни. Хоча безпосередньо його наслідки відчула порівняно невелика частини респондентів (лише у 4,5\% опитаних

1 Тут і далі в тексті для наводяться дані загальнонаціональних опитувань, що проводяться Інститутом соціології НАН України щорічно, починаючи з 1994 р. у формі соціологічного моніторингу (тобто повторних опитувань за однаковою методикою). Вибіркова сукупність кожного опитування в середньому становить 1800 осіб і репрезентує доросле населення України (віком від 18 років). За типом побудови вибірка $\epsilon$ триступеневою, стратифікованою, випадковою, із квотним скринінгом на останньому щаблі, що дає можливість репрезентувати населення України за типом поселення (обласний центр/місто/село), статтю, віком і рівнем освіти. Похибка вибірки не перевищує 2,3\%. Починаючи 32013 р. опитування проводиться у період червеньлипень. 


\section{ДИНАМІКА УЯВЛЕНЬ НАСЕЛЕННЯ УКРАЇНИ ПРО УКРАЇНО-РОСІЙСЬКІ ВІДНОСИНИ В УМОВАХ НАПРУЖЕНОСТІ МІЖДЕРЖАВНИХ СТОСУНКІВ (2014-2017 рр.)}

близькі родичі брали участь у збройному конфлікті), збройний конфлікт постійно підживлює стан напруженості у суспільстві. Попри певне озвичаєння самого факту збройного протистояння, про що свідчить зокрема падіння страху перед нападом зовнішнього ворога на Україну, (у 2014 р. цього боялися 59,7 \% опитаних, а у 2017 р. - лише 38,4\%), рутинізувати війну досить складно. Сам факт тривалого протистояння, в якому постійно гинуть люди, є джерелом постійної тривоги та неспокою. Про це свідчить і те, що прихильниками продовження бойових дій як способу вирішення конфлікту наразі є лише $15 \%$ опитаних.

Хоча конфлікт цей розгортається на території України у масовій свідомості населення він прямо пов'язується 3 втручанням Росії. До речі і у самій Росії, за даними Всеросійського центру дослідження громадської думки, які були отримані в той самий період за такою ж методологією ${ }^{2}$ одним із головних джерел страхів росіян $є$ «міжнародна напруженість, конфлікти між країнами, військові дії» [2].

Повертаючись до українського контексту, зазначимо, що напередодні подій 2014 р., коли відбулася анексія Криму почалося збройне протистояння на Донбасі, що і спровокувало радикальне посилення напруженості у російськоукраїнських відносинах, ставлення населення України до Росії було переважно позитивним. В опитування 2013 р. на питання «Кого Ви бачите головним союзником Украӥни у найближчі 5 років?» 48 \% респондентів вважали, що ними мають бути Росія та країни СНД. Натомість Європейський Союз бачили у цій ролі лише $29,6 \%$ опитаних, а США тільки $2,4 \%$.

Досить позитивно сприймалася й ідея приєднання України до союзу Росії й Білорусі. Скоріше позитивно ставилися до цього $49 \%$ опитаних, а скоріше негативно - 28,5\%. Проте подальший перебіг подій різко змінив ставлення українців. Попри всі заяви Росії про ії непричетність до подій на Донбасі і намагання представити приєднання Криму як результат волевиявлення населення півострову, реакція населення України була досить одностайною. За даними опитування 2014 р. засуджували приєднання до Росії Автономної республіки Крим 75,3\% опитаних, а підтримували - лише 10,2\% (решта вагалися 3 відповіддю). Подібною була реакція і на збройне протистояння на Сході. Майже половина опитаних (47,2 \%) розцінювало ці події як приховану агресію з боку Росії.

2 Всеросійське опитування проведено у серпні 2017 р. Обсяг вибірки - 1600 осіб. Вибірка репрезентує населення РФ у віці 18 років і старше за статтю, віком, освітою, типом поселення. Вибірка багатоступенева стратифікована, 3 покроковим відбором домогосподарств, із застосуванням квот на останньому етапі відбору. Для даної вибірки максимальний розмір помилки (з урахуванням дизайн-ефекту) з імовірністю $95 \%$ не перевищує $3,5 \%$. 


\section{ДИНАМІКА УЯВЛЕНЬ НАСЕЛЕННЯ УКРАЇНИ ПРО \\ УКРАЇНО-РОСІЙСЬКІ ВІДНОСИНИ В УМОВАХ НАПРУЖЕНОСТІ \\ МІЖДЕРЖАВНИХ СТОСУНКІВ (2014-2017 рр.)}

Відповідно і ставлення до відносин з Росією змінилося 3 точністю до навпаки. Тепер ідею приєднання України до союзу Росії та Білорусі скоріше підтримували 24,8 \%, а ставилися до цього негативно 54 \% опитаних. Змінилося i бачення головних союзників України. Тепер населення переважно орієнтувалося на Європейський Союз (44 \%), посилилася, хоча і не надто сильно на той момент, орієнтація на США $(9,1 \%)$, а Росію та інші країни СНГ обрали у якості союзників $18,5 \%$.

У масовій свідомості починають поступово формуватися нові уявлення про бажані орієнтири розвитку стосунків з іншими країнами. Оскільки одразу радикально трансформувати сформовану у попередній період картину, де колишні «друзі і союзники» перетворилися на «ворогів», а колишні «вороги» стали «потенційними друзями», практично неможливо, реакцією значної частини населення стає намагання дистанціюватися від усякого співробітництва. Відповідаючи на питання «Якому шляху розвитку України Ви віддаєте перевагу?», найчастіше респонденти обирають варіант «опиратися, перш за все, на власні ресурси, зміцнюючи незалежність» $(35,2 \%)$. Поступово набирає прихильників думка про те, що треба «встановлювати зв’язки, першою чергою, 3 розвиненими країнами Заходу» $(26,1 \%)$. Проте певні сподівання все ще пов’язані зі східнослов'янським блоком (Україна, Росія, Білорусь), зміцнювати який хотіли б 12,2\%. До того ж розвиток зв'язків у межах СНД все ще підтримують 5,8\%. Частина опитаних не змогла визначитися $(10,7 \%)$ або підтримала думку, що різні регіони країни мають обирати власний шлях $(4,5 \%)$.

Водночас відмова від «особливих» стосунків 3 Росією стає майже доконаним фактом, розвивати відносини переважно 3 нею були налаштовані лише 4,1 \%. У цих умовах постає проблема нового позиціонування населення України щодо відносин з Росією. Відповідно, починаючи 32014 р., в моніторингу Інституту соціології НАНУ з'являється питання «Якими б Ви хотіли бачити відносини України з Росією?» На сьогодні фіксується наступна картина змін в уявленнях про бажані варіанти цих стосунків (табл. 1).

Таблиця 1

Динаміка уявлень населення України про російсько-українські відносини, \%

\begin{tabular}{|l|l|l|l|l|}
\hline \multicolumn{1}{|c|}{ Можсливі варіанти стосунків } & 2014 & 2015 & 2016 & 2017 \\
\hline $\begin{array}{l}\text { Вони мають бути такими, як між сусідніми державами - } \\
\text { візами та митницями на кордоні }\end{array}$ & 37,0 & 47,9 & 44,0 & 39,8 \\
\hline $\begin{array}{l}\text { Вони мають бути такими, як між дружніми державами - без } \\
\text { віз та митниць на кордоні }\end{array}$ & 36,2 & 35,2 & 32,6 & 36,8 \\
\hline $\begin{array}{l}\text { Україна і Росія мають об’єднатися в економічний союз - 3 } \\
\text { вільним пересуванням товарів і робочої сили }\end{array}$ & 12,1 & 10,5 & 13,8 & 11,9 \\
\hline Україна і Росія мають об’єднатися в одну державу & 2,2 & 2,4 & 2,7 & 3,1 \\
\hline Важко відповісти & 12,5 & 4,0 & 6,9 & 8,4 \\
\hline
\end{tabular}




\section{ДИНАМІКА УЯВЛЕНЬ НАСЕЛЕННЯ УКРАЇНИ ПРО УКРАЇНО-РОСІЙСЬКІ ВІДНОСИНИ В УМОВАХ НАПРУЖЕНОСТІ МІЖДЕРЖАВНИХ СТОСУНКІВ (2014-2017 рр.)}

Одразу можна помітити, що найбільш суттєві коливання фіксуються переважно у групі тих, хто не визначився. Причому коливання ці хвилеподібні, їхня частка то падає, то зростає і при тому не перерозподіляється рівномірно по усіх групах, а помітно поповнює лише одну з них. Сам по собі цей факт доволі важливий, оскільки він зафіксований на тлі радикальних змін у міждержавних відносинах між Україною та Росією, які відбуваються протягом усього періоду спостережень. Згадаймо, наприклад, такі яскраві маркери цього протистояння як визнання Верховною Радою України Росії країною-агресором, фактичний крах торгових відносин, розрив культурних обмінів, введення обмежень щодо в’їзду російських громадян лише з біометричними паспортами тощо. У таких умовах зміни уявлень населення про україно-російські стосунки виглядають доволі незначними. Наповнення груп, які віддали перевагу тому чи іншому варіанту стосунків з Росією, яке було зафіксовано у 2014 р. порівняно 32013 р., надалі змінювалося по-різному.

Як ми вже бачили вище, радикальні зміни в оцінці населенням міждержавних стосунків відбулися між 2013 р. та 2014 р.. Але фактично зникла лише ідея приєднання України до союзу Росією та Білорусі, яку наразі негативно сприймає $62,1 \%$ опитаних. Трансформація уявлень про характер стосунків між країнами відбувається не по типу розриву, а по типу дистанціювання. При чому, у 2015 р. ця тенденція посилювалася. На той момент за даними дослідження майже $60 \%$ респондентів сприймали російську агресію як таку, що має тенденцію до ескалації. Зокрема 28,5 \% вважали, що Росія має намір захопити всі Південно-Східні області України, 14,8 \% очікували захоплення усієї Донецької та Луганської областей, 8,6 \% очікували можливого захоплення усієї України, а 7,2 \% вважали, що Росія прагне захопити не лише Україну, а й Молдову та країни Прибалтики. I лише 18,4\% не були згодні 3 жодним з перелічених варіантів (решта - 22,6 \%, вагалася 3 відповіддю). Проте призупинення активного збройного протистояння сприяло гальмуванню страхів. Відповідно режим «холодної ввічливості», який переводить Росію у розряд «рядового сусіда», від якого слід якомога сильніше відмежуватися, не набуває значного поширення. Це зокрема підтверджують i дані спільного всеукраїнського репрезентативного соціологічного дослідження, здійсненого чотирма провідними соціологічними службами України у листопаді 2017 p. ${ }^{3}$

На основі отриманих результатів можна констатувати що трансформація картини міждержавних стосунків все ще триває. Значна частина опитаних (40 \%)

\footnotetext{
${ }^{3}$ Опитування проводилося за вибіркою, яка репрезентує доросле населення України за такими ознаками як: стать, вік (від 18 років), область проживання, тип поселення (місто/село). Опитано 20000 респондентів. Статистична похибка вибірки: не більше $0,7 \%$
} 


\section{ДИНАМІКА УЯВЛЕНЬ НАСЕЛЕННЯ УКРАЇНИ ПРО \\ УКРАЇНО-РОСІЙСЬКІ ВІДНОСИНИ В УМОВАХ НАПРУЖЕНОСТІ \\ МІЖДЕРЖАВНИХ СТОСУНКІВ (2014-2017 рр.)}

залишається прихильниками дистанціювання, обираючи при визначенні шляху України варіант «визначити свій власний шлях розвитку та спиратися на свої ресурси». Водночас поляризація стає дедалі виразнішою. Наразі варіант «Рухатись в бік Росії та відновлення добросусідських відносин з країнами СНД» обрали лише 9,7\% опитаних, а варіант «рухатися в бік Свропи, інтеграції 3 країнами ЄС»-44,4%. При цьому не визначилося лише 5,5 \% респондентів.

Водночас доки ситуація на Донбасі не нормалізується остаточно ставлення до Росії буде залишатися досить обережним. Більше того, за даними того ж дослідження, майже половина опитаних $(45,9 \%)$ вважає, що після закінчення війни на сході України стосунки з Росією слід підтримувати на мінімально необхідному рівні, а 21,8\% взагалі налаштовано на те, щоб не підтримувати з Росією жодних стосунків.

Повертаючись до результатів моніторингу Інституту соціології НАН України, слід відмітити ще одну важливу рису динаміки уявлень про україноросійські стосунки на сучасному етапі. Вона також пов'язана з неможливістю швидких радикальних перетворень в уявленнях про стосунки України та Росії, зважаючи на різноманітні форми близькості між населенням країн. Дослідження підтверджує, що негативне сприйняття сусідньої країни, фокусується, насамперед, на їі очільниках, а не на пересічних росіянах. Зокрема, відповідаючи на питання «Хто, на Ваму думку, своӥми діями (бездіяльністю) найбільше впливає на погіршення ситуащії в нашій країні?», 27,8 \% респондентів поклали таку відповідальність на керівників Російської Федерації. Таким чином створюється певний клапан, який дозволить зменшувати стан напруженості у міждержавних стосунках України та Росії. Особливо, зважаючи на те, що на сьогодні сталим є сприйняття ситуації в контексті військового протистояння. Це підтверджує, зокрема той факт, що характеризуючи те, що сьогодні відбувається в Україні, 37,7 \% опитаних, вважають, що в Україні продовжується боротьба із зовнішнім ворогом (Росією).

Насамкінець слід зазначити, що уявлення про україно-російські стосунки $\epsilon$ доволі однорідними в різних соціальних та демографічних групах і практично не диференційовано за ознаками статі, віку, освіти, місця проживання. Єдиною характеристикою, за якою можна простежити суттєві відмінності, є регіон.

Підтверджено, що громадська думка населення України щодо того, яким має бути бажаний характер відносин з Росією, значною мірою диференційована внаслідок відмінностей політико-ідеологічних настанов різних соціальних груп і має чіткі регіональні відмінності: на Заході превалює тенденція до дистанціювання, 66,8 \% опитаних у цьому регіоні бачать відносини з Росією, які побудовані на засадах чіткого розмежування, з візами та митницями на кордоні. На Півдні та Сході сильнішою є схильність до відновлення добросусідських 


\section{ДИНАМІКА УЯВЛЕНЬ НАСЕЛЕННЯ УКРАЇНИ ПРО \\ УКРАЇНО-РОСІЙСЬКІ ВІДНОСИНИ В УМОВАХ НАПРУЖЕНОСТІ \\ МІЖДЕРЖАВНИХ СТОСУНКІВ (2014-2017 рр.)}

відносин. Дистанціюватися хотіло б трохи більше чверті опитаних (по 27 \% у кожному 3 регіонів), а по $40 \%$ прагнуть повернутися до дружніх добросусідських стосунків без митниць і кордонів. Натомість у центральному регіоні відповідні настановлення представлені у рівних пропорціях - 39\% за чітке розмежування, $40 \%$ - за добросусідство.

Результати проведеного дослідження дають можливість зробити наступні висновки щодо трансформацій уявлень населення України про україноросійські відносини в умовах напруженості міждержавних стосунків у період 2014-2017 рр.:

- україно-російські відносини є одним з чинників, що визначає стан соціальної напруженості в українському суспільстві;

- у масовій свідомості українців сформовано уявлення про неможливість у сьогоднішніх умовах приєднання України до союзу Росії та Білорусі;

- уявлення про україно-російські відносини знаходяться в стані трансформації, необхідність відмови від типових маркерів «дружньої» або «ворожої» держави, що не відображають сучасні реалії, компенсується через формування уявлення про необхідність опертя на власні ресурси на шляху до подальшого розвитку країни;

- в уявленнях про україно-російські відносини образ добросусідської держави поступово перетворюється на образ держави-сусіда, яка втрачає статус «дружньої», але остаточно не набуває статусу «ворожої»;

- можливість збереження позитивного ставлення українців до близьких та знайомих, що проживають в Росії підтримується завдяки компенсаторній ролі, яку відіграє спрямування негативу, що виникає внаслідок недружніх дій Росії по відношенню до України, на керівництво Російської Федерації;

- регіональні відмінності в динаміці уявлень про україно-російські стосунки виявляються у тенденціях до відновлення співробітництва i добросусідства (превалює на Півдні та на Сході України) та до дистанціювання (превалює на Заході).

Висновки. Отримані результати мають суттєве значення як для розуміння процесів трансформації масової свідомості, так і для вироблення ефективних засобів соціально-психологічного впливу на формування уявлень населення про майбутнє україно-російських відносин 3 метою запобігання проявам ксенофобії та закріпленню у масовій свідомості негативних диспозицій стосовно населення країн-сусідів.

\section{Список використаних джерел:}

1. Злобіна О. Міжнародні відносини vs відносини між народами: взаємосприйняття українців та росіян в умовах загострення стосунків між 
країнами / О. Злобіна // Україна і світ: теоретичні та практичні аспекти діяльності у сфері міжнародних відносин : матеріали Міжнар. наук.-практ. конф., м. Київ 19-20 квіт. 2017 р. - Київ : Вид. центр КНУКіМ, 2017. - Ч. 2. С. 234-242.

2. Карта страхов россиян: итоги лета [Электронныий ресурс]. - Режим доступа: https://wciom.ru/index.php?id=236\&uid=116418. - Загл. с экрана. - Дата обращения 23.02.2018.

3. Прес-реліз за результатами соціологічного дослідження [Електронний ресурс]. http://www.kiis.com.ua/?lang=ukr\&cat=reports\&id=724\&page=2. $\quad-\quad$ Назва 3 екрану. - Дата звернення 23.02.2018.

\section{References:}

1. Zlobina, O. (2017) International relations vs. the relations between peoples: mutual understanding of Ukrainians and Russians in conditions of aggravation of relations between countries. Ukraine and the world: theoretical and practical aspects of activity in the field of international relations: material of the scientific and practical conference, Ukraine., Kyiv, April 19-20, 2017. Kyiv: KNUKiM Publishing, Vol. 2, pp. 234-242.

2. Map of fears of the Russians: the results of the summer. [online] Available at : https://wciom.ru/index.php?id=236\&uid=116418. [Accessed 23 February 2018]. Title from the screen.

3. Press-reliz for the results of sociological additions. [online] Access mode: http://www.kiis.com.ua/?lang=ukr\&cat=reports\&id=724\&page=2.

[Accessed 23 February 2018]. Title from the screen.

(C) Злобіна О. Г., 2018 